Int. J. Dev. Biol. 57: 115-121 (2013)

doi: $10.1387 / \mathrm{ijdb} .130069 \mathrm{md}$

\title{
From testis to teratomas: a brief history of male germ cells in mammals
}

\author{
MASSIMO DE FELICl* and SUSANNA DOLCI \\ Department of Biomedicine and Prevention, University of Rome Tor Vergata, Rome, Italy
}

\begin{abstract}
In antiquity, many theories were advanced on reproduction and the functions of the gonads. The male genitalia were called "testes" probably from the Latin word "testis " that originally meant "witnesses", because they provide evidence of virility. Through the first dissection of the seminipherous tubules by Renier de Graaf (1668), the discovery of spermatozoa by Antonj van Leeuwenhoek (1677) and in vitro fertilization by Spallanzani (1780) and later by George Newport and George Vines Ellis (1854), it was only in the early part of the XIX century when it was realized that testes produce spermatozoa and that they are essential for egg fertilization and subsequent embryo development. In the period between the end of the XIX and the beginning of the XX century, scientists such as Albert von Kölliker (1817-1910), Franz von Leydig (1821-1908), Enrico Sertoli (1842-1910) and Gustaf Retzius (1842-1919) did microscopic observations of testis that marked the history of male germ cells and established the bases for the development of contemporary in vitro culture and molecular studies that are revealing the deeper secrets of male germ cells. Among these, those by Leroy Stevens on embryonal carcinoma cells in the early 1950s led to the present concepts that germ cells and cancer cells share several characteristics and that a close relationship exists between germ cells and stem cells, these being two pillars of modern developmental biology.
\end{abstract}

KEY WORDS: germ cell, teratoma, teratocarcinoma, testis, stem cell

\section{From Aristotle to the Reinaissance}

Although it was appreciated from the antiquity that removal of gonads had evident consequences for the fertility and behaviour of men, the anatomy and function of the gonads were essentially unknown in the ancient times. In antiquity, many theories were advanced on reproduction and the significance of the gonads. Until the Renaissance, most physicians described the male and female reproductive organs as counterparts of each other and wrote of homologous anatomical structures. Words such as "testes" were applied to both male and female reproductive organs, since it was believed that both produce substances by similar processes that contributed to generation. What that substance was became a matter of heated debate. The male genitalia were called "testes" probably from the Latin word "testis " that originally meant "witnesses", because they provide evidence of virility. In the fourth century B.C., Aristotle wrote that man contributed the form of humanity through his semen, while woman contributed only brute matter, a substance less pure and less sanctified than semen itself. Hippocrates and Galen preferred to describe human conception as occurring from two "seeds" though they differed slightly on the relative importance of the male and female contribution. Debates about the different seeds continued throughout the Middle Ages. According to the Galenic model, both men and women were believed to have "seminal vessels" that carried semen to its point of exit. How male semen was generated was a source of speculation. Galen argued that semen came from the testes but other sources were hypothesized. Did it come from the brain via the spinal cord? Was it produced from blood? From the Renaissance onward, the development of human anatomy begun to change the traditional images of the reproductive organs and the vocabulary for the male and female bodies slowly became much more specific to each sex. At the end of the XV century, Leonardo's in his earliest anatomical drawings (about 1493) depicting sexual intercourse, admirably summarizes the traditional views of that time about the origin of semen (Fig. 1). Notably, in the middle of $\mathrm{XVI}$, Andreas Vesalius (1514-1564), considered the father of the

Abbreviations used in this paper: EC cell, embryonic carcinoma cell; PGC, primordial germ cell.

\footnotetext{
*Address correspondence to: Massimo De Felici. Department of Biomedicine and Prevention, University of Rome Tor Vergata, Via Montpellier 1, 00133 Roma, Italy.e-mail: defelici@uniroma2.it
}

Final, author-corrected PDF published online: 5 June 2013.

ISSN: Online 1696-3547, Print 0214-6282 


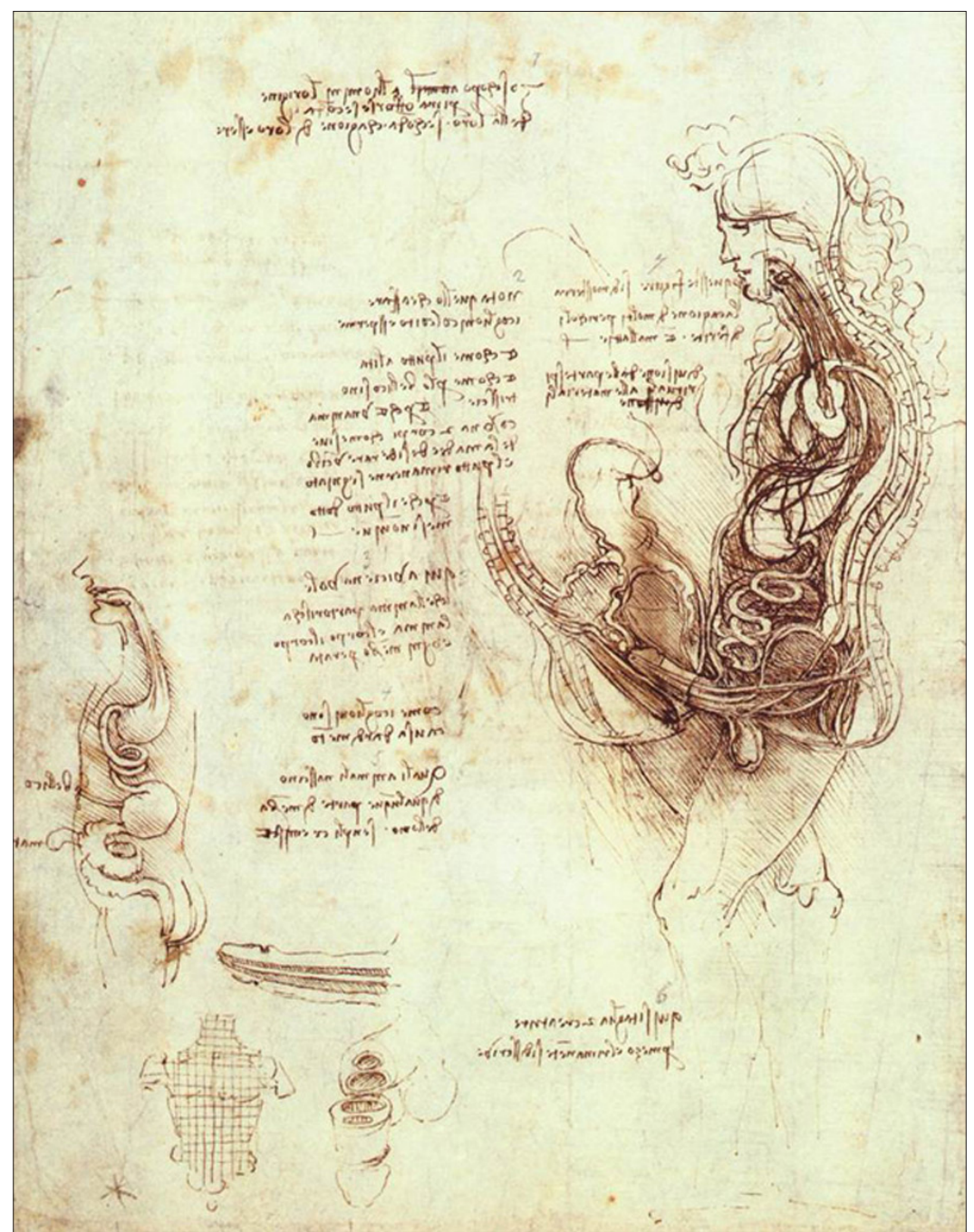

Fig. 1. Leonardo's drawing of sexual intercourse (about 1493). In order to provide the view that semen derives from the brain and travels down the spinal cord, Leonardo drew a nerve from the spinal cord to the upper of two canals in the penis. In contrast, to accommodate the Galen's view that semen came from the testes, Leonardo drew a tube from the testes to the lower canal, which was thought to be used for the passage of urine as well as semen.

human anatomy, in The Humani Corporis Fabrica, still described the reproductive woman's organs as similar counterparts of those of man's (Fig. 2). The view emphasizing difference among the sexes, however, slowly become prevalent. Organs that used to be associated with both sexes started to have their own names as a result of the discovery of the sperm and eggs. Testis begun to designate unambiguously the male gonad, ovary the female equivalent. As soon as organs were given different medical names, they were seen to be markedly different from each other. Such information was the product of increased dissection and ultimately the introduction of the microscope as a tool of investigation.

\section{The discovery of animacules (sperm), their production by testes and role in conception}

At the middle of the $\mathrm{XVI}$ century, the knowledge of the function of the testes was, however, still modest. Renier de Graaf (1641-1673) puts it rather succinctly: "From the many theories of the great authorities just now adduced, it is clear that the field of knowledge concerning the testicles, about which they talk in such diverse ways, is entangled with many great unsolved problems. Certainly they ought to have waited longer before claiming that they knew the truth. I hope that they will pardon us for saying that no one has yet elucidated in writing the real substance of the testicles". de Graaf performed also an elegant experiment on a mouse testis: "If the tunica albuginea is removed and the tubules thrown into a basin of water and shaken about a little, you will behold a delightful and surprising sight; the tubules will separate from one another in such a way that without any help from instruments it can be seen with absolute clarity that the substance of the testicles consists wholly of tubules" (Fig. 3). He makes the conclusion that: "If anyone asks us what is really the character of the substance of the testicles, we shall say that is it is simply a collection of minute vessels or tubules which confect semen; if these same tubules were disentangled without being broken and tied to one another, they would far exceed 20 Dutch ells (one Dutch ell corresponds to $70 \mathrm{~cm}$ ) in length". Shortly before his early death at 32 ages, de Graaf in a letter to the Royal Society in London directed the Society's attention to "a certain most ingenious man named Leeuwenhoek". The name of Antonj van Leeuwenhoek (1632-1723) is strictly linked to the construction of the first rudimental microscopes and the first observations of cells and microorganisms. He was also the first to conduct rigorous observations on human spermatozoa. The story of the discovery of spermatozoa, by Leeuwenhoek, or more likely by his student Johan Ham, is well known (see (Castellani, 1973). In 1677, Leeuwenhoek reported to the Royal Society how, by means of his home-made microscope, he had observed in his own semen millions of vigorously swimming spermatozoa: "I have often observed the semen of a healthy man without waiting for it to become corrupt or fluid, five or six minutes after ejaculation. I have noticed that a large number of small animals, I think it must be more than a thousand, on an area no larger than a grain of sand". The members of the Society were very interested in the 'living creatures' in semen and consequently the Secretary wrote back a request that he examines the semen of other species. van Leeuwenhoek's new observations revealed enormous numbers of spermatozoa in the testicles and vasa deferentia of a wide variety of other animals. In 1683 he wrote that he was now more certain than ever that: " man comes not from an egg but from an animalcule in the masculine seed". Actually, a major controversy in Embryology during this period was that of preformism affirming that organisms develop from miniature versions of themselves and all parts of the embryo and future organism exist completely formed in the germ cell and develop only by increasing in size; inside the preformationist some, spermistsclaimed the homonculus must come from spermatozoo, others, ovists, who located the homonculus in the egg. In the case of a male, the homunculus in the sperm was clearly illustrated by Nicolas Hartsoeker (1656-1725) (Hartsoeker, 1694) (Fig. 4). In contrast, the concept of epigenesis stated that an 


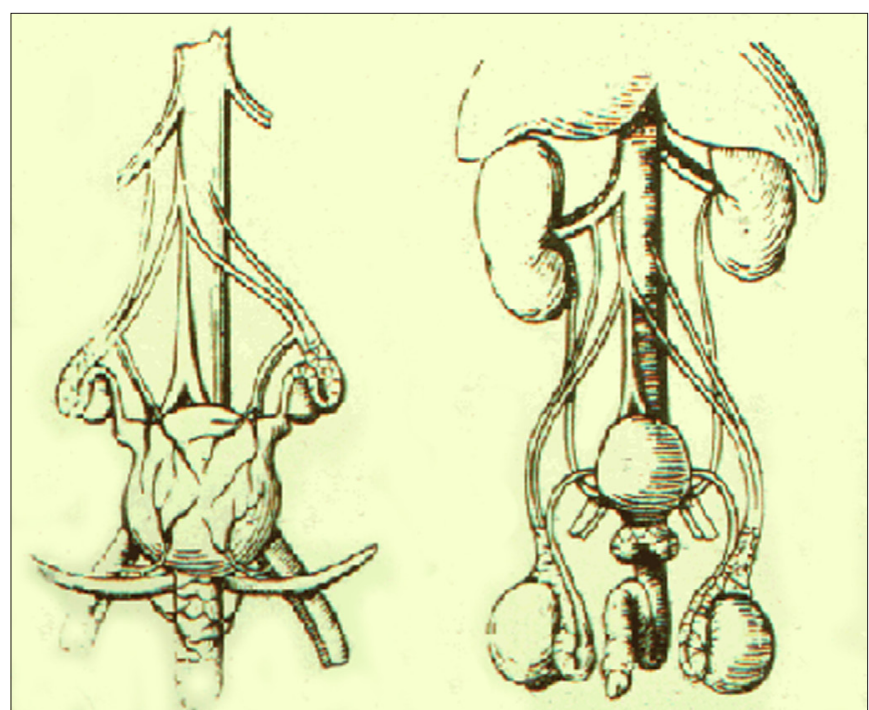

Fig. 2. Vesalius's representation of female and male genitalia. He saw the female genitalia as internal representations of the male genital; the illustration is from his major work, De Humani Corporis Fabrica (1543).

individual develops by structural elaboration from an unstructured egg, rather than by simple enlargement of a preformed entity. About, 100 years later, the Italian scientist Lazzaro Spallanzani (1729-1799), demonstrated unequivocally for the first time that semen was essential for fertilization (see Castellani, 1973, De Felici, 2001). He examined semen from mammals, fish and amphibians and confirmed the presence of spermatozoa. In experiments with frogs, he was able to show that oocytes would only develop into tadpoles after contact with semen, possibly the first example of in vitro fertilization. Notwithstanding these clever experiments, Spallanzani still thought that "spermatic worms" played no role in fertilization. On the basis of his experiments, he still believed according to the preformism that the seminal fluid stimulated the foetal heart, which lay preformed inside the egg, and triggered development. The discovery of the vast numbers of motile creatures in semen stimulated a lot of debate as to their origin and function because at the time it was far from obvious that they might be the agents of conception. Many scientists were convinced that they must be parasites. The name spermatozoa was first used by von de Baer in 1827 (von de Baer, 1827) and reflects this view. Some speculated that spermatozoa were essential for conception, whilst others thought that they werea

Fig. 3 (left). Dissection of a testes by Renier de Graaf (1641-1673). It shows that after removing tunica albuginea, it "consists wholly of tubules"; the illustratiuon is from De Virorum Organi Generationi Inservientibus (1668).

Fig. 4 (right) . Original drawing by Nicolas Hartsoeker (1656-1725) in his Essay de dioptrique (1694) in which the preformitionism theory of spermists, the homunculus in the sperm, was clearly illustrated. normal component of semen, but that they performed a secondary role such as mixing the other seminal components. After nearly a century from the experiments of Spallanzani, in 1853, George Newport and George Vines Ellis showed, again using frogs, that sperm actually penetrated the oocyte and were essential for fertilization (Newport, 1854). In 1874, Eduard van Beneden first observed fertilization in mammals (van Beneden, 1874). In the early part of XIX century, the Swiss physician, Jean-Louis Prevost and the French scientist, Jean-Baptiste Dumas made a major contribution to the field with their exhaustive comparative investigations showing that spermatozoa were present in the testes of many different animals (see (De Felici, 2001). They concluded that the spermatozoa must be produced in the testes. Their work was heavily criticized at the time because it was perceived as a reversion to the outdated animalculist theories of the XVIII century, but in the longer term it lent significant weight to the mounting evidence for the importance of the spermatozoa contribution to the reproductive process. Most of their research work was published in the Annales des Sciences Naturelles in the period 1821-1830. Contrary to the generally accepted view, they asserted that spermatozoa were not parasites but instead were the "result of a true secretory action and the active principle of fecundation".

\section{Histological dissections of the human testes: Kolliker, Leydig, Sertoli and Retzius}

The detailed histological observations of the Swiss scientist, Albert von Kölliker (1817-1905), were pivotal in demonstrating that spermatozoa were not parasites, but motile autologous cells which developed from testicular cells by the process of histogenesis (von Kolliker, 1852). Celebrated for his microscopic work on tissues, von Kölliker demonstrated the cellular nature of eggs and sperm, showing that sperm are formed from the tubular walls of the testis "just as pollen grains are formed from cells of the anthers" (Fig. 5). Like for the notion that testes produce sperm, the endocrine
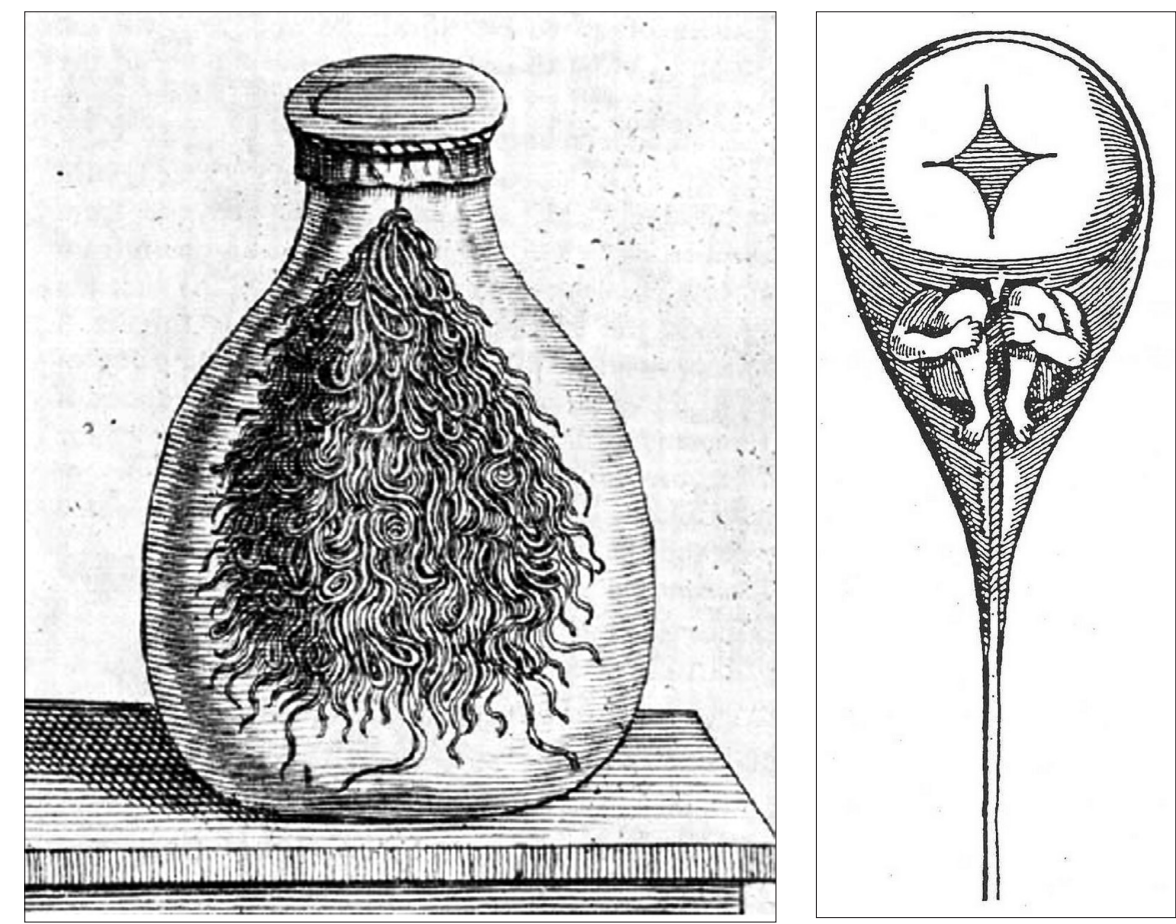
function of testes has evolved only in the last 300 years. Ancient Egyptian and Chinese civilizations castrated a servile class of men called eunuchs; it was noted that eunuchs were less aggressive than other men, but the link of this behaviour to testosterone was not made until recently. It was the experiment by Arnold Adolph Berthold in Göttingen (1803-1861) which clearly demonstrated that a substance was produced in the testis with effect on secondary sex characters (Berthold, 1849). It is unclear what prompted Berthold to perform his experiments on four castrated cocks. Two had testes transplanted and developed as normal cocks, while the other two remained capons. Two additional cockerels had one testis removed but developed normally. Berthold concluded that: "The testes act upon the blood, and the blood acts upon the whole organism". Between the middle of the XVIII and the beginning of XIX centuries, the two basic functions of testes in producing spermatozoa and hormones responsible for sexual characteristics of male were slowly disclosing. Also the histological structures of the testis were more detailed described. In 1850, Franz von Leydig (Leydig, 1850) describes the interstitial cells which were later termed from him the "Leydig's cells": "These special cells are present in small numbers where they follow the course of the blood vessels, but increase in mass considerably when surrounding seminiferous tubule". However, only more than 100 years after in 1958, the first evidence that such cells produce androgens was achieved by histochemical techinique (Wattenberg, 1958). In 1865, Enrico Sertoli (1842-1910) described the cells in the tubules which came to bear his name (Sertoli, 1865). Sertoli chose to use human tissues for his observations and focused exclusively on human testis throughout his career. He used several types of preparations, including microdissections of individual seminiferous tubules, thin sections of dried tissues and squashed pieces of fresh tissues. Sertoli first described the non-spermatogenic cells of the seminiferous tubules as "cellule ramificate" (branched cells) and "cellule madri" (mother cells), suggesting their function. He drew

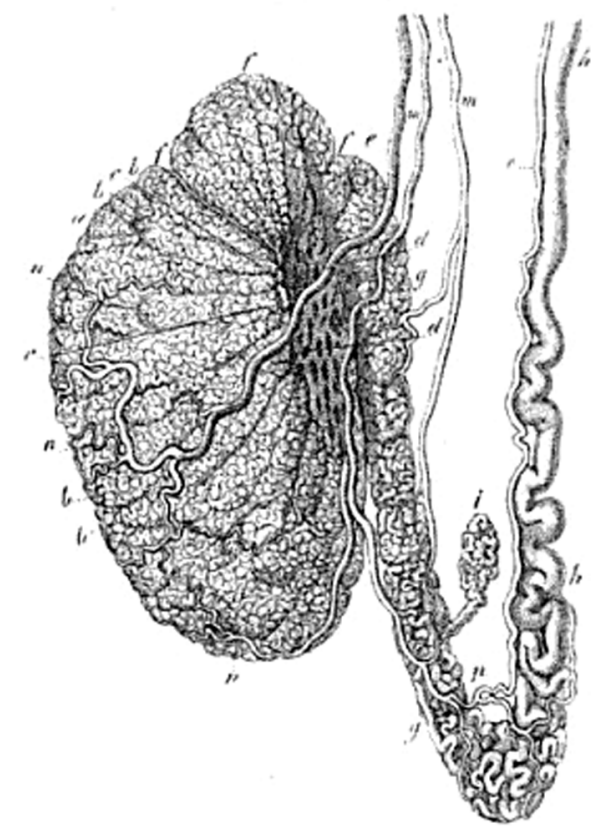

Fig. 5. Detailed drawing of the testis from Handbuch der Gewebelehre des Menschen (1852; Manual of Human Histology) by Albert von Kölliker (1817-1905).
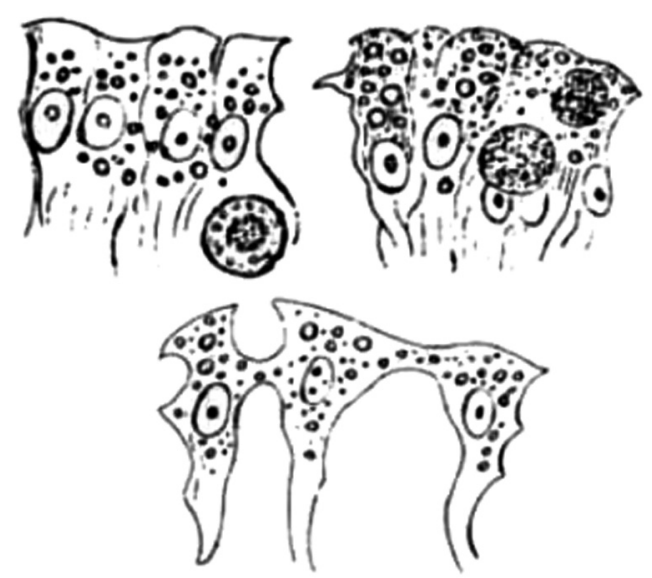

Fig. 6. Original drawings of the "human branched cells" later termed Sertoli cells by Enrico Sertoli (from: Dell'esistenza di particolari cellule ramificate nei canalicoli seminiferi del testicolo umano (About the existence of branched cells in the seminipherous tubules of the huma testis), Morgagni 7: 31-33, 1865).

in great details what he observed through his microscope (Fig. 4). In addition to his use of the term "mother cells", last section of his 1865 paper (Dell'esistenza di particolari cellule ramificate nei canalicoli seminiferi del testicolo umano, About the existence of branched cells in the seminipherous tubules of the human testis; Fig. 6), is remarkable. He states: "It is likely that these cells do not produce the spermatozoa. The formation of the spermatozoa would be consistent neither with the form of the branched cells, which are different from the seminiferous cells, the real progenitors of the spermatozoa, nor with their constant position inside the tubule, nor their tendency to enclose the seminiferous cells among their branches, nor finally their communication with one another through the extensions". Later investigators, including Merkel, Boll and Ebner, confirmed Sertoli's report about the existence of "cellule ramificate" in the seminiferous tubules, and they were referred to as Sertoli cells ever after (see,(Setchell, 1993)). In 1878, Sertoli published in two parts also a detailed description of spermatogenesis, in which he showed that spermatozoa derived from nematoblasts (round spermatids as we called them now). Sertoli also described the development of the seminiferous cells (spermatocytes) dividing it into three stages, corresponding to what we now refer to as leptotene/zygotene, pachytene and diplotene. He identify two types of spermatogonia and a spermatogenic wave, estimating its length, and finally showed that germ cells often occurred in groups with cytoplasmic bridges between cells. The Sertoli's papers followed those of von Ebner and Merkel, who in 1871 had given an account of spermatogenesis in the rat describing, although some time erroneously, various germ cell types and associations in the seminipherous epithelium (see(Setchell, 1993). In the period at the end of XIX and the beginning of XX century, Gustaf Retzius (1842-1919) did microscopic observations of sperm that were to become the standard towards which other scientists would attempt. The eleventh volume of Biologische Untersuchungen, Neue Folge, from the year 1904 is the first volume to contain several papers on sperm structure (Retzius, 1904-1921). The importance of Retzius's work resides in two main features. One was the technical excellence; his investigations were at the peak of what could and can be achieved by light microscopy. The second was that he examined the contents of the epididymal ducts or the seminiferous tubes or 
the isolated spermatozoa from over 400 animal species, out of which nearly half were vertebrates (Retzius, 1933-1948).

\section{The concept of the seminipherous epithelium cycle}

The introduction of electron microscopy in 1930 greatly expanded the knowledge of mammalian spermatogenesis (for references, see De Kretser and Kerr, 1988). Two of the most important discoveries in the past century in the field of spermatogenesis were the identification of the seminiferous epithelial cycle in mammals (Clermont, 1972, Clermont et al., 1993, De Kretser and Kerr, 1988, Leblond and Clermont, 1952), as well as the hypothalamic-pituitary-testicular axis that regulates spermatogenesis (Sharpe, 1994). We like here to remind Prof. Valerio Monesi, who was a pioneer in studying the cell cycle in mouse spermatogenesis and in introducing the concept of stem cell spermatogonia (Siracusa and Stefanini, 2000).

\section{In vitro studies}

An important contribution to understanding male germ cell biology came from in vitro culture systems (for a review, see Staub, 2001). Champy first reported differentiation of male germ cells in vitro in cultures of small parts of testis from adult rabbits in blood (Champy, 1920). Champy observed spermatogonial mitosis in the first week and newly formed leptotene primary spermatocytes after 9 days of culture. Martinovitch produced brilliant results as early as 1937 (Martinovitch, 1937). He cultured gonads obtained from rats and mice just after birth in a medium devised by (Fell and Robison, 1929). Martinovitch observed the long-lasting survival of gonadal tissues in a system that allowed the testicular architecture to be maintained; pachytene primary spermatocytes were formed after 11 days of culture from newborn mouse testes. In 1952, Wolff reported that undifferentiated mouse gonads (10.5-11.5 days post coitum) could differentiate in vitro either into ovaries or testes after 4 to 6 days of culture. The medium employed ensured a good development of the somatic tissue of the gonads, but not the survival and differentiation of germ cells. At the beginning of the 60', Anna and Emil Steinberger, together with William Perloff, began studying the long-term survival of testicular fragments in vitro (Steinberger et al., 1964). They made changes in several culture conditions that allowed important progress in testicular culture. Their work is still of great significance today for biology researchers who want to reproduce spermatogenesis in vitro. The possibility to reproduce important part of the meiotic differentiation of germ cells in culture, brought precise data on its timing which corresponds to the kinetics of the differentiation of germ cells in their natural environment (Steinberger and Steinberger, 1965). Their results, first obtained with rats, were confirmed with human testicular biopsies (Steinberger, 1967). After these first attempts, many others researchers devised methods for culture of fragments and whole testis from embryos, prepuberal and adult males. Seminiphreous tubules and different types of isolated testicular cells were also studied in vitro (for references, see Staub, 2001). Particularly important in the context of this special issue, were the development of in vitro culture systems for the primordial germ cells (PGCs) (for reviews, see De Felici, 2001, De Felici et al., 2004) and spermatogonia (Dolci et al., 2001).
Information about mouse PGC growth factor requirement for survival and proliferation and the improvement of the in vitro culture conditions for such cells led to the production of the pluripotent ES-like cell lines (EG cells) from mouse and humans PGCs which represent a model for the formation of teratomas/teratocarcinomas (Matsui et al., 1992, Resnick et al., 1992). Likewise, the progress in spermatogonia in vitro culture were the basis to obtain germline cell-derived pluripotent cell (GPSC alias maGSC, mGS), which is derived from spermatogonial stem cells (SSCs) (Kanatsu-Shinohara et al., 2003, Kubota and Brinster, 2008).

\section{Leroy Stevens and testicular teratomas/teratocarcinoma}

Parallel to the increasing knowledge about spermatogenesis, in the early 50' the first studies on testicular teratomas/teratocarcinomas begun. In 1953, Leroy Stevens, while studying the adverse effects of tobacco on mice at the Jakson Laboratory found that a strain then called 129 , developed spontaneously gigantic scrotums (Kelly, 2007). He found that the testes of these mice contained bizarre tissue aggregates of teeth, cartilage, hair and other tissues. What Stevens first described is a particular type of tumor, called teratoma, from the Greek word "teraton" which means monster (Fig. 7). Teratomas, a definition first applied by Virchow in late seventies of the nineteenth century (Vircow, 1863) originate from germ cells and have ability to develop into a bizarre array of tissues. After his initial discovery, Stevens abandoned his tobacco research and focused his studies on teratomas. A year later, coauthorizing a paper with Little (Stevens and Little, 1954) they found that disaggregated cells from the original teratomas were able to reproduce the tumour when transplanted into singenic animals. Pierce and his co-workers (Pierce et al., 1957) then established that testicular teratomas not only contained all three embryonic germ layers but they also showed histologically undifferentiated elements composed of embryonal carcinoma cells (EC cells), the key malignant pluripotent stem cell of these tumours. The term teratocarcinoma thus is generally used for tumours containing both $\mathrm{EC}$ and teratoma components. Pierce demonstrated that single undifferentiated cells isolated from a mouse teratocarcinoma, when

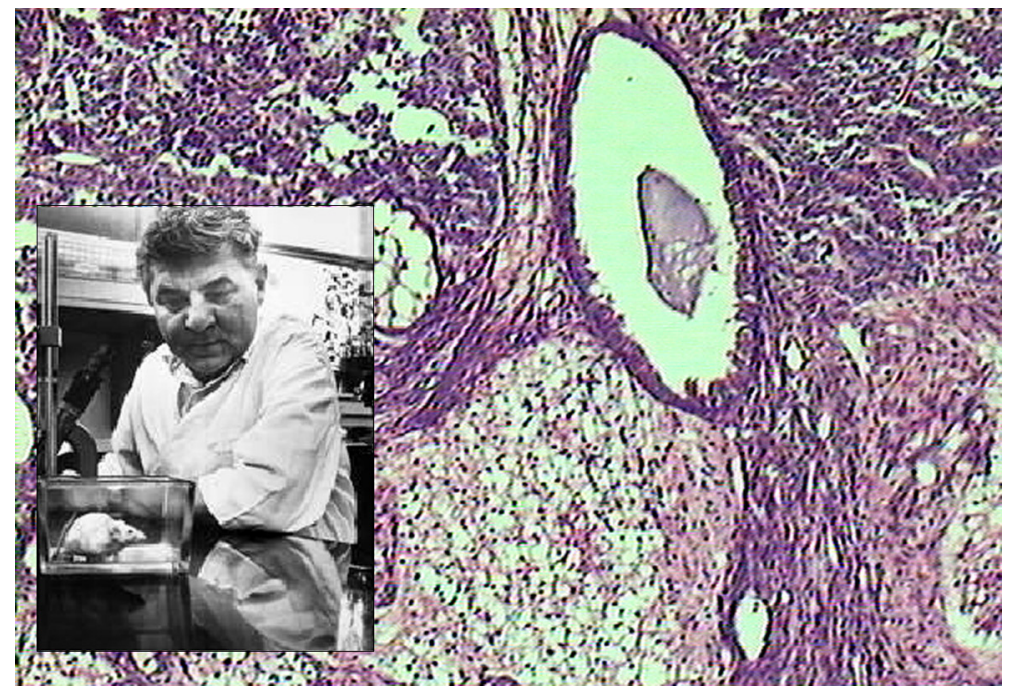

Fig. 7. Leroy Stevens (Jackson Laboratory) and an example of a testicular teratoma produced by embryonic germ cells after transplantation into a host testis. 
transferred into normal mice, gave rise to malignant teratocarcinomas that contained differentiated tissues representative of all three major germ cell layers. These discoveries gave birth to the stem cell biology era.

Trying to go back to teratocarcinoma cellular roots, Stevens showed that this tumour can be induced experimentally by explanting gonadal ridges of foetuses, between 11.5 and 13.5 days post coitum of development, to ectopic sites (Stevens, 1967) and that teratoma formation occurs during fetal development in the highly susceptible 129/SvJ strain (Noguchi and Stevens, 1982, Stevens, 1967). Teratomas or teratocarcinomas were also obtained from many strains of mice by the transplantation of early embryos, at the egg cylinder stage (about 7 days of development) to ectopic sites (Solter et al., 1970). Several mutations that are inherited as Mendelian traits affect testicular germ cell tumour susceptibility in 129/Sv mice. Among these, Ter (Noguchi and Noguchi, 1985) strongly increases teratoma susceptibility, affecting at homozygosity almost $100 \%$ of males (Lam et al., 2007). Only recently Ter has been mapped to a point mutation in the third exon of the RNA-binding protein (RBP) dead end homolog 1 (Dnd1/Ter) that leads to nonsense-mediated decay and loss of protein (Youngren et al., 2005).

Since the discovery of EC cells many efforts were done to maintain these cells in vitro clonally. The isolation of several EC cell lines also from humans and the study of their biology has revealed that they represent a broad spectrum of differentiation potential ranging from pluripotent ES-like cells (which can be incorporated into a mouse blastocyst taking part in the development of a chimera) to nullipotent EC cells which are blocked in their commitment to differentiation. In 1972 Niels Skakkebaek identified abnormal intratubular germ cells (CIS) as the likely precursors of invasive teratocarcinomas (Skakkebaek, 1972).

The studies on EC cells gave an important contribution to our understanding of embryo development and some aspects of stemness. Moreover, they paved the way to the production of embryonic stem cells by Martins Evans and Gail Martin (Martin and Evans, 1974).

\section{Present times}

In the last thirty years, technological advancements have greatly increased our understanding of spermatogenesis and the pathologies related to misregulation of germ cell development, namely the teratomas/teratocarcinomas formation. These include the use of proteomics and genomics (Calvel et al.) and mouse genetic models (Verhoeven et al., 2010) to examine different aspects of spermatogenesis. Other aspects of spermatogenesis that have received major attention are the regulation of apoptosis (Shaha et al., 2010); the roles of oestrogens (Carreau and Hess, 2010, Carreau et al., 2010), and androgens (Verhoeven et al., 2010, Walker, 2010) in spermatogenesis; non-genomic action of testosterone and its impact on spermatogenesis (Walker, 2010); the regulation of mitosis and meiosis during spermatogenesis (Wolgemuth and Roberts, 2010); impact of environmental toxicants and lifestyle effects on spermatogenesis (Sharpe, 2010); spermatogonial stem cell biology (Phillips et al., 2010); transcriptional regulation of spermatogenesis (Bettegowda and Wilkinson, 2010). Moreover, other important studies relating to spermatogenesis, such as the biology of spermatogonial stem cells (Kanatsu-Shinohara et al.,
2008), have significantly impacted other studies in the field, such as the possible use of spermatogonial stem cells for therapeutic applications (i.e. producing non-reproductive tissues for transplantation applications) (Simon et al., 2009). Most of these areas of research are discussed in this Special Issue. There are many areas that require additional research. For instance, while we have acquired a great deal of knowledge about the transcriptional regulation of spermatogenesis during the past decade, only a few genes (or gene sets) are known to regulate spermatogenesis at the transcriptional level. Moreover, how these genes interact with each other to regulate diverse cellular events during spermatogenesis such as mitosis, meiosis and spermiogenesis remains largely unknown. However, we remain hopeful that significant advances will continue to be made in the next decade.

\section{Acknowledgements}

The authors were supported by MIUR PRIN 2012.

\section{References}

AFZELIUS, B. (1995). Gustaf Retzius and spermatology. Int. J. Dev. Biol. 39: 675-685. BERTHOLD, A.A. (1849). Transplantation of testes. English translation by D. P. Quiring 1944. Bull. Hist. Med 16: 399-401.

BETTEGOWDA, A. and WILKINSON, M.F. (2010). Transcription and post-transcriptional regulation of spermatogenesis. Philos Trans $R$ Soc Lond B Biol Sci 365: 1637-1651.

CALVEL, P., ROLLAND, A.D., JEGOU, B. and PINEAU, C. Testicular postgenomics: targeting the regulation of spermatogenesis. Philos Trans $R$ Soc Lond B Biol Sci 365: 1481-1500.

CARREAU, S. and HESS, R.A. (2010). Oestrogens and spermatogenesis. Philos Trans $R$ Soc Lond B Biol Sci 365: 1517-1535.

CARREAU, S., WOLCZYNSKI, S. and GALERAUD-DENIS, I. (2010). Aromatase, oestrogens and human male reproduction. Philos Trans $R$ Soc Lond B Biol Sci 365: 1571-1579.

CASTELLANI, C. (1973). Spermatozoan biology from Leeuwenhoek to Spallanzani. $J$ Hist Biol 6: 37-68.

CHAMPY, C. (1920). Quelques re'sultats de la me'thode de culture des tissus. Arch Zool Exp Gen 60::461-500.

CLERMONT, Y. (1972). Kinetics of spermatogenesis in mammals: seminiferous epithelium cycle and spermatogonial renewal. Physiol Rev 52: 198-236.

CLERMONT, Y., OKO, R. and HERMO, L. (1993). Cell biology of mammalian spermatogenesis. Oxford University Press., New York, NY.

DE FELICI, M. (2001). Twenty years of research on primordial germ cells. Int J Dev Biol 45: 519-522.

DE FELICI, M., SCALDAFERRI, M.L., LOBASCIO, M., IONA, S., NAZZICONE, V., KLINGER, F.G. and FARINI, D. (2004). Experimental approaches to the study of primordial germ cell lineage and proliferation. Hum Reprod Update 10: 197-206.

DE KRETSER, D. and KERR, J. (1988). The cytology of the testis. Raven Press, New York, NY.

DOLCI, S., PELLEGRINI, M., DIAGOSTINO, S., GEREMIA, R. and ROSSI, P. (2001) Signaling through extracellular signal-regulated kinase is required for spermatogonial proliferative response to stem cell factor. J Biol Chem 276: 40225-40233.

FELL, H.B. and ROBISON, R. (1929). The growth, development and phosphatase activity of embryonic avian femora and limb buds cultivated in vitro. Biochem. J. 23: 767

HARTSOEKER, N. (1694). Essay de dioptrique. Jean Anisson 24-25.

KANATSU-SHINOHARA, M., OGONUKI, N., INOUE, K., MIKI, H., OGURA, A., TOYOKUNI, S. and SHINOHARA, T. (2003). Long-term proliferation in culture and germline transmission of mouse male germline stem cells. Biol Reprod69:612-616.

KANATSU-SHINOHARA, M., TAKEHASHI, M. and SHINOHARA, T. (2008). Brie history, pitfalls, and prospects of mammalian spermatogonial stem cell research. Cold Spring Harb Symp Quant Biol 73: 17-23. 
KELLY, E.B. (2007). Stem Cells Today Greenwood Publishing Group.

KUBOTA, H. and BRINSTER, R.L. (2008). Culture of rodent spermatogonial stem cells, male germline stem cells of the postnatal animal. Methods Cell Biol 86: 59-84.

LAM, M.Y., HEANEY, J.D., YOUNGREN, K.K., KAWASOE, J.H. and NADEAU, J.H. (2007). Trans-generational epistasis between Dnd1Ter and other modifier genes controls susceptibility to testicular germ cell tumors. Hum Mol Genet 16:2233-2240.

LEBLOND, C.P. and CLERMONT, Y. (1952). Definition of the stages of the cycle of the seminiferous epithelium in the rat. Ann N Y Acad Sci 55: 548-573.

LEYDIG, R. (1850). ZurAnatomie der mannlichen Geschlechtsorgene und Analdrusen der Saugerthiere. $Z$ Wiss Zool 2: 1-57.

MARTIN, G.R. and EVANS, M.J. (1974). The morphology and growth of a pluripotent teratocarcinoma cell line and its derivatives in tissue culture. Cell 2: 163-172.

MARTINOVITCH, P.N. (1937). Development in vitro of the mammalian gonad. Nature 139: 413.

MATSUI, Y., ZSEBO, K. and HOGAN, B.L. (1992). Derivation of pluripotential embryonic stem cells from murine primordial germ cells in culture. Cell 70: 841-847.

NEWPORT, G., VINER ELLIS, G.,. (1854). Researches on the Impregnation of the Ovum in the Amphibia; and on the Early Stages of Development of the Embryo. (Third Series) Phil. Trans. R. Soc. Lond. 144: 229-244.

NOGUCHI, T. and STEVENS, L.C. (1982). Primordial germ cell proliferation in fetal testes in mouse strains with high and low incidences of congenital testicular teratomas. J Natl Cancer Inst 69: 907-913.

PHILLIPS, B.T., GASSEI, K. and ORWIG, K.E. (2010). Spermatogonial stem cell regulation and spermatogenesis. Philos Trans R Soc Lond B Biol Sci365: 1663-1678.

PIERCE, B., VERNEY, E.L. and DIXON, F.J. (1957). The biology of testicular cancer. I. Behavior after transplantation. Cancer Res 17: 134-138.

RESNICK, J.L., BIXLER, L.S., CHENG, L. and DONOVAN, P.J. (1992). Long-term proliferation of mouse primordial germ cells in culture. Nature 359: 550-551.

RETZIUS, G. (1904-1921). Biologische UntersuchungenNeue Folge Volumes XI-XIX.

RETZIUS, G. (1933-1948). Biografiska anteckningaroch minnen. Almqvist \& Wiksell, Uppsala.

SERTOLI, E. (1865). De l'esistenza di particolari cellule ramificate nei canalicoli seminiferi del testicolo umano. Morgagni 7: 31-41.

SETCHELL, B.P. (1993). The Sertoli Cell. Cache River Press.

SHAHA, C., TRIPATHI, R. and MISHRA, D.P. (2010). Male germ cell apoptosis: regulation and biology. Philos Trans $R$ Soc Lond B Biol Sci 365: 1501-1515.

SHARPE, R.M. (1994). Regulation of spermatogenesis Raven Press, New York, NY. SHARPE, R.M. (2010). Environmental/lifestyle effects on spermatogenesis. Philos
Trans $R$ Soc Lond B Biol Sci 365: 1697-1712.

SIMON, L., EKMAN, G.C., KOSTEREVA, N., ZHANG, Z., HESS, R.A., HOFMANN, M.C. and COOKE, P.S. (2009). Direct transdifferentiation of stem/progenitor spermatogonia into reproductive and nonreproductive tissues of all germ layers. Stem Cells 27: 1666-1675.

SIRACUSA, G. and STEFANINI, M. (2000). Valerio Monesi, a pioneer of modern Reproductive Biology. Int J Dev Biol 44: 555-557.

SKAKKEBAEK, N.E. (1972). Possible carcinoma-in-situ of the testis. Lancet2:516-517.

STAUB, C. (2001). A century of research on mammalian male germ cell meiotic differentiation in vitro. J Androl 22: 911-926.

STEINBERGER, A. and STEINBERGER, E. (1965). Differentiation of Rat Seminiferous Epithelium in Organ Culture. J Reprod Fertil 9: 243-248.

STEINBERGER, A., STEINBERGER, E. and PERLOFF, W.H. (1964). Mammalian Testes in Organ Culture. Exp Cell Res 36: 19-27.

STEVENS, L.C. (1967). Origin of testicular teratomas from primordial germ cells in mice. J Natl Cancer Inst 38: 549-552.

STEVENS, L.C. and LITTLE, C.C. (1954). Spontaneous Testicular Teratomas in an Inbred Strain of Mice. Proc Natl Acad Sci USA 40: 1080-1087.

VAN BENEDEN, E. (1874). De la distinction originelle du testicule et de l'ovaire, caractare sexuel des deus feuillets pnmordiaux de l'embryon, hermaphroditism morphologique de toute individualite animale: Essai d'une theorie de la fécondation,". Bull. Acad. Roy. Sci. Belg. 37 530-595.

VERHOEVEN, G., WILLEMS, A., DENOLET, E., SWINNEN, J.V. and DE GENDT, K. (2010). Androgens and spermatogenesis: lessons from transgenic mouse models. Philos Trans R Soc Lond B Biol Sci 365: 1537-1556.

VIRCOW, R. (1863). Die krankhaften Geschwiilste. Berlin

VON DE BAER, K.E. (1827). Ovi Mammalium et Hominis genesi.

VON KOLLIKER, A. (1852). Handbuch der Gewebelehre fur Ärzte und Studierende.

WALKER, W.H. (2010). Non-classical actions of testosterone and spermatogenesis. Philos Trans R Soc Lond B Biol Sci 365: 1557-1569.

WATTENBERG, L.W. (1958). Microscopic histochemical demonstration of steroid-3 beta-ol dehydrogenase in tissue sections. J Histochem Cytochem 6: 225-232.

WOLGEMUTH, D.J. and ROBERTS, S.S. (2010). Regulating mitosis and meiosis in the male germ line: critical functions for cyclins. Philos Trans $R$ Soc Lond $B$ Biol Sci 365: 1653-1662.

YOUNGREN, K.K., COVENEY, D., PENG, X., BHATTACHARYA, C., SCHMIDT, L.S., NICKERSON, M.L., LAMB, B.T., DENG, J.M., BEHRINGER, R.R., CAPEL, B. et al., (2005). The Ter mutation in the dead end gene causes germ cell loss and testicular germ cell tumours. Nature 435: 360-364. 